\title{
Effect of pre-milking teat preparation procedures on the microbial count on teats prior to cluster application
}

Gleeson D, O’Brien B, Flynn J, O’ Callaghan E and Galli F

Teagasc, Moorepark, Dairy Production Research Centre, Fermoy, Co. Cork

\section{ABSTRACT}

A study was carried out to investigate the effect of six pre-milking teat preparation procedures on lowering the staphylococal, streptococcal and coliform microbial count on teat skin prior to cluster application. The teat preparations included 'Iodine', 'Chlorhexidine' teat foam, 'Washing and drying' with paper, 'No preparation', 'Chlorine' teat foam, and disinfectant 'Wipes'. Teat preparations were applied for five days to 10 cows for each treatment during two herd management periods (indoors and outdoors). Teats were swabbed on day four and five before teat preparation and repeated after teat preparation. The swabs were plated on three selective agars: Baird Parker (Staphylococcus spp.), Edwards (Streptococcus spp.), and MacConkey (coliform). Following incubation, microbial counts for each pathogen type were manually counted and assigned to one of six categories depending on the microbial counts measured. The results were analysed by logistic regression using SAS (2004). The main analysis was conducted on binary improvement scores for the swabbing outcomes. There were no differences for staphylococcal, streptococcal and coliform bacterial counts between treatments, measured 'before' teat preparation. Treatments containing 'Chlorhexidine' teat foam (OR=4.46) and 'Wipes' $(\mathrm{OR}=4.46)$ resulted in a significant reduction $(\mathrm{P}<0.01)$ in the staphylococcal count on teats compared to 'Washing and drying' or 'No preparation'. 'Chlorine' teat foam $(\mathrm{OR}=3.45)$ and 'Wipes' (3.45) had the highest probability $(\mathrm{P}<0.01)$ of reducing streptococcal counts compared to 'Washing and drying' or 'No preparation'. There was no statistical difference between any of the disinfectant treatments applied in reducing coliforms. Thus, the use of some disinfectant products for pre-milking teat preparation can have beneficial effects on reducing the levels of staphylococcal and streptococcal pathogens on teat skin.

KEYWORDS: cows, microbial counts, swabs, teat preparation

\section{CORRESPONDING AUTHOR:}

\section{David Gleeson}

Teagasc, Moorepark, Dairy Production Research Centre, Fermoy Co Cork, Ireland

E-mail: david.gleeson@teagasc.ie

Tel: +3532542269

Fax: +3532542340

Irish Veterinary Journal volume 62 Number 7 461-467 2009

\section{INTRODUCTION}

Mastitis represents a major economic cost to dairy farmers with losses of up to $€ 190$ per case depending on severity (Berry and Amer 2006) and €60 per cow for the average milk supplier (O'Brien 2008). The losses associated with mastitis include discarded milk, increased number of culled cows, cost of antibiotic treatment and reduced milk quality and price (Hutchison et al. 2005; Kagkli et al. 2007). Even though, it has been shown that factors such as genetic characteristics, impaired immune-function, feeding regimes (Myllys and Rautala 1995) and machine milking (O'Shea 1987; Barkema et al. 1999) are related to mastitis, poor milking hygiene has been associated with increased somatic cell count (SCC), reduced milk production and inferior milk quality (Ingawa et al. 1992; Miller et al. 1993; Myllys and Rautala 1995). Machine milking may also be considered as a major cause of bacterial cross contamination from cow to cow. However, a good pre- milking hygiene routine can decrease the cow infection ratio by not only reducing udder bacterial contamination from the environment, but also reducing bacterial contamination from other infected animals (Grindal and Bramley 1989; Ingawa et al. 1992; Hutchison et al. 2005). Newbould (1970) showed a positive relationship between bacteria presence on teats and new intramammary infection. Staphylococcus aureus is one of the major and more virulent pathogens that can cause mastitis infection and lactating cows can be considered one of the main reservoirs of this species. Moreover, Staphylococcus aureus colonisation of teat skin increases the risk of Staphylococcus aureus intrammmary infection (Matthews et al. 1992; Roberson et al. 1994; Myllys and Rautala 1995). The aim of any teat cleaning routine is not only to reduce mastitis infection risk, but also to enhance milk quality. Magnusson et al. (2006) showed that teat cleaning reduced the milk spore content by $96 \%$. Vissers et al. 
(2007) also showed that spore concentration in milk was highly correlated with spore concentration on teats; hence milk bacterial spores most likely originated from dirt and faeces attached to the teats at the time of milking. Many methods of pre-milking udder preparation are practiced by producers and overall, one of the most important aspects of pre-milking udder hygiene is udder dryness at the time of machine attachment (Galton et al. 1982; Ingawa et al. 1992; Visser et al. 2007). Bacteria contaminated water can also increase milk bacterial counts (Ingawa et al. 1992; Visser et al. 2007). A commonly used pre-milking teat preparation method involves washing teats by hand with water and drying teats with a paper towel just before the machine is attached (Ingawa et al. 1992). There is strong evidence that among all pre-milking procedures, wet cleaning treatment, followed by paper towel manual drying will result in the lowest bacterial counts (Galton et al. 1982; Galton et al. 1986: McKinnon et al. 1990; Gibson et al. 2008): this practice is particularly effective in reducing milk bacterial contamination during the winter housing period (McKinnon et al. 1990). Similar seasonal bacterial infection trends linked to the pasturing/housing routine have been observed by Hutchison et al. (2005).

As an alternative to washing and drying teats, many producers now dip teats pre-milking with various disinfectant products such as iodophor solution, iodine based gel, sodium hypoclorate, dodecyl benzene sulfonic acid (DDBSA), chlorine, chlorhexidine, phenolics and alcohol (Galton et al. 1986; McKinnon et al. 1990; Watts et al. 1991; Ingawa et al. 1992; Oliver et al. 1993; Wilson et al. 1997; Oliver et al. 2001, Foret et al. 2005, Gibson et al. 2008). Ingawa et al. (1992) showed that both iodine based gel and 0.5\% iodophor solution significantly reduced milk bacterial count and clinical mastitis occurrence compared to teat washing and drying with paper towels. However, Oliver et al. (1993, 2001) showed that pre-milking disinfection with $0.25 \%$ iodine dip or phenolics solution did not reduce the incidence of clinical mastitis when compared to post-milking disinfection only. However, Pankey et al. (1987) reported that predipping reduced the rate of intrammamary infection with major mastitis pathogens such as Staphylococcus aureus, Streptococcus agalactiae and coliforms. In addition to iodine products, chorhexidine when used as a pre-dip, significantly decreased SCC values in herds infected with mastitis (Wilson et al. 1997). Furthermore, Gibson et al. (2008) concluded that a chlorine based dip followed by a dry wipe was an effective pre-milking treatment for controlling cow mastitis. The benefit of using some disinfectant products pre-milking in reducing new mastitis infection has been demonstrated. A study by Roberson et al. (1994) demonstrated that teat orifices colonised with Staphylococcus aureus were 3.3 times more likely to have intramammary infection. Therefore, reducing the microbial count on teats prior to milking is an important step in the prevention of mastitis. The type of disinfectant product used as a pre-dip may have varying degrees of success in reducing the microbial count on teats (Gibson et al. 2008). However, there is no knowledge on the effect of pre-milking disinfection using a range of newly-formulated teat disinfectants in reducing the microbial counts on teats. Thus, the objective of this study was to investigate the effectiveness of six different pre-milking teat preparation procedures on lowering the staphylococcal, streptococcal and coliform bacterial count on teat skin.

\section{MATERIALS AND METHODS}

Six pre-milking teat preparations were applied to spring calving Holstein Friesian cows during two herd management periods, while cows were housed (indoors) and while cows were grazed on pastures (outdoors). During the indoor period and for the previous three months, cows were housed in an easy-feed slatted house with matted cubicle beds and dressed with lime daily to maintain a dry bed. During the outdoor period and for the previous three months, cows were grazed under a rotational grazing system and moved every 24 hours to new pasture. Ten cows which were free from clinical mastitis infection were randomly chosen for each pre-milking preparation for a period of five days per treatment. The six pre-milking applications applied are identified as 'Washing and drying', 'lodine', 'Chlorhexidine', 'Chlorine', 'Wipes' and 'No preparation'. The preparations applied are described in detail in Table 1.

An iodine $(2.0 \% \mathrm{w} / \mathrm{v})$ teat disinfectant (1-4 mix) containing emollients was applied as a post-milking teat disinfectant

Table 1: Description of pre-milking teat preparation treatments

\begin{tabular}{|l|l|l|l|l|}
\hline $\begin{array}{l}\text { Application } \\
\text { description }\end{array}$ & Supplier & Product name & Ingredients & Application method \\
\hline Wash/dry & None & None & None & Manual \\
\hline lodine & $\begin{array}{l}\text { JohnsonDiversey } \\
\text { Jamestown Road, Finglas, Dublin } \mathbf{1 1}\end{array}$ & Deosan Super lodip & $\begin{array}{l}\text { lodine + glycerine } \\
\text { Spray }\end{array}$ \\
\hline Chlorhexidine & $\begin{array}{l}\text { JohnsonDiversey } \\
\text { Jamestown Road, Finglas, Dublin } \mathbf{1 1}\end{array}$ & Deosan Teat Foam & $\begin{array}{l}\text { Chlorhexidine, } \\
\text { biguanide, vantocil }\end{array}$ & Cup \\
\hline Chlorine & $\begin{array}{l}\text { Ecolab } \\
\text { Genus Breeding Ltd, Alpha Building, London Road, Nantwich, CW5 7 JW }\end{array}$ & Valiant Teat Foam & Chlorine Dioxide & Cup \\
\hline Wipes & $\begin{array}{l}\text { Byotrol Agrisphere } \\
\text { Technology Ltd, Riverside Works, Collyhurst Rd, Manchester M40 7RU }\end{array}$ & Dairysan Wipes & $\begin{array}{l}\text { Didecyldimonium } \\
\text { Lauralkonium } \\
\text { Chloride }\end{array}$ & Manual \\
\hline No preparation & None & None & None & None \\
\hline
\end{tabular}


to the following treatments, 'lodine', 'Washing and drying', 'No preparation' and disinfectant 'Wipes' using an in-parlour sprayer. 'Chlorhexidine' teat foam and 'Chlorine' teat foam were used for post-milking disinfection, for the respective pre-milking treatments. The same foam products were used for post-milking disinfection, as it was considered more likely that where the foam products are used on farms as a pre-milking disinfectant, they would also be used for post-milking disinfection. The possibility of a teat skin reaction if different pre- and post- teat disinfectant products were used was also considered. Analysis of the bacterial counts on teats prior to teat preparation showed no effects of using different post milking disinfectant products. The 'Chlorine' teat foam product was prepared daily by mixing a foam active base and activator (50/50). Teat cups designed for applying teat foam were used to apply these products. The entire circumference of the teat was covered in teat foam by immersing each individual teat in the teat cup. 'Iodine' was applied as a pre-milking disinfectant by spray, as this was considered the most common application method on Irish farms. Approximately, $15 \mathrm{mls}$ of iodine was applied to the teats of each cow when used as a pre and post milkinf disinfectant. Teat disinfection was carried out by one operator for all products. The concentration of each disinfectant product ingredients was not disclosed by the manufacturer. Teats disinfected pre-milking were dried with individual disposable paper towels approximately 30 seconds after the disinfectant was applied and prior to milking. Teats that were washed pre-milking were dried with individual disposable paper towels. Cows were milked in a 20-unit, 80-degree side-by-side milking parlour and were milked in the morning at 07:30h and in the afternoon at 15:30h. Cows were exposed to each pre-milking preparation for a period of five days, for each management period at both the morning and afternoon milking. On day four and five, all teats from each cow were swabbed using one sterile swab (Cultiplast, LP Italian SPA, Via Carlo Reale, 15/4, 20157, Milano, Italy) per cow before teat preparation and repeated after teat preparation at the morning milking (Table 2). The sterile swab was rubbed across the teat orifice and down the side of each teat avoiding contact with the udder hair or cows flank at all times. A small number of teats $(<7 \%)$ that were considered excessively soiled with faeces, and where swabbing of the teat skin was not possible, were excluded from swabbing (Table 2). In addition, by omitting these soiled teats, the potential contamination of the agar plates was avoided. In those instances, the remaining three teats from the cow were swabbed. There were no differences in the number of excluded teats between treatments or management periods. Teat swabbing and teat preparation was carried out by one operator for all treatments.

Immediately after teat swabbing was completed, the swabs were placed in individual sterile bottles containing $5 \mathrm{mls}$ of Tryptic Soy Broth (BD. BBL ${ }^{\mathrm{TM}}$ Trypticase ${ }^{\mathrm{TM}}$ Soy Broth (Soybean-Casein Digest Broth). The broth was manufactured by Becton, Dickinson and Company, Sparks, MD 21152 USA.38800 Le Pont-de-Claix, France. The broth was prepared in $500 \mathrm{ml}$ amounts and autoclaved at $121^{\circ} \mathrm{C}$ for 15 minutes, and then distributed into $5 \mathrm{ml}$ aliquots in a laminar flow cabinet. The sterile bottles containing the swabs were frozen $\left(-20^{\circ}\right)$ awaiting laboratory analysis for the presence of staphylococcal, streptococcal, and coliforms. The swabs were subsequently plated on three separate selective agars: Baird Parker (staphylococcal), Edwards (streptococcal), and MacConkey (coliforms). Specific bacteria types within each category were not defined. Following incubation at $37^{\circ} \mathrm{C}$ for 24 hours, microbial counts (CFU/ml) for each pathogen type were manually counted and assigned to one of six categories depending on the bacterial counts measured. (1= no pathogen present, $2=1$ to $10,3=11$ to $20,4=>20$, 5 = numerous, 6 = infinite).

Table 2: Swabbing procedure carried out before and after teat preparation for six pre-milking teat preparation procedures

\begin{tabular}{|c|c|c|c|c|c|}
\hline \multirow[t]{3}{*}{ Application description } & \multirow{3}{*}{ Management period } & \multicolumn{4}{|c|}{ Before teat preparation** } \\
\hline & & \multicolumn{2}{|c|}{ Day 1} & \multicolumn{2}{|c|}{ Day 2} \\
\hline & & No of swabs* & No of teats & No of swabs* & No of teats \\
\hline \multirow[t]{2}{*}{ Wash/dry } & Indoor & 10 & 39 & 10 & 39 \\
\hline & Outdoor & 10 & 38 & 10 & 39 \\
\hline \multirow[t]{2}{*}{ lodine } & Indoor & 10 & 40 & 10 & 37 \\
\hline & Outdoor & 10 & 38 & 10 & 38 \\
\hline \multirow[t]{2}{*}{ Chlorhexidine } & Indoor & 10 & 39 & 10 & 39 \\
\hline & Outdoor & 10 & 40 & 10 & 39 \\
\hline \multirow[t]{2}{*}{ Chlorine } & Indoor & 10 & 38 & 10 & 39 \\
\hline & Outdoor & 10 & 40 & 10 & 38 \\
\hline \multirow[t]{2}{*}{ Wipes } & Indoor & 10 & 39 & 10 & 39 \\
\hline & Outdoor & 10 & 39 & 10 & 38 \\
\hline \multirow[t]{2}{*}{ No preparation } & Indoor & 10 & 39 & 10 & 38 \\
\hline & Outdoor & 10 & 37 & 10 & 38 \\
\hline
\end{tabular}




\section{STATISTICAL ANALYSIS}

The results were analysed by logistic regression using SAS (2004). Preliminary analysis of the results for before and after treatment was by fitting generalised logits for the multinomial response because, while the response was ordinal in nature, the data did not meet the assumptions of a proportional odds model. The main analysis was conducted on binary improvement scores for the swabbing outcomes. 1 = lower category count after treatment and 0 = same or greater category count after treatment. Standard maximum likelihood estimation of the regression could not proceed because of the technical condition of quasicomplete separation for the effects. An alternative strategy due to Heinze and Schemper (2002) was implemented using their SAS macro code.

\section{RESULTS}

There were no differences in the levels of staphylococcal, streptococcal and coliform bacterial counts measured on teats (assigned to different teat preparations) 'before' teat preparation. However, there was a significant reduction $(P<0.001)$ in the levels of staphylococcal pathogens on teats after teat preparation with all treatments except the ‘No preparation' pre-milking treatment. The probability of a reduction in the staphylococcal counts tended to be higher $(\mathrm{P}<0.06)$ for cows managed outdoors compared too indoors. Treatment with 'Chlorine' teat foam resulted in a $30 \%$ reduction in staphylococcal counts when used on cows at pasture compared to its use on cows indoors, likewise 'Iodine' and 'Wipes' resulted in an increased staphylococcal count reduction of $18 \%$ and $20 \%$, respectively, when used on cows at pasture (Table 3). On the other hand 'Chlorhexidine' teat foam had a $20 \%$ greater reduction in bacterial counts when used on housed cows, compared to cows at pasture. However, the median reduction in the staphylococcal count for all treatments was $21 \%$ better for cows on pasture compared to its use on housed cows. The probability of a reduction in streptococcal bacterial counts in response to overall teat preparation was not significantly different between indoor and outdoor management periods. However, some pre-milking treatments resulted in greater reductions in counts when used on cows housed compared to when used on cows at pasture and vice versa. The treatment containing 'Iodine' resulted in a $26 \%$ greater reduction in streptococcal counts when used on cows indoors compared to when used on cows at pasture (Table 3). Similarly, the 'Chlorhexidine' teat foam treatment had a $20 \%$ greater reduction when used indoors, compared to when used on cows outdoors. However, both the 'Chlorine' and disinfectant 'Wipes' teat preparation treatments resulted in a $30 \%$ greater reduction when used outdoors compared to when used on cows indoors. The reduction observed for 'coliform' counts was low for both indoor and outdoor management periods (Table 3). However, the probability of a greater response to teat preparation for 'coliform' bacteria is more likely outdoors $(\mathrm{OR}=0.27 ; \mathrm{P}<0.05)$ compared to indoors (Table 4).

Table 4 shows the association between pre-milking teat preparation procedure and management period on the probability of a reduction in the microbial levels of staphylococcal, streptococcal and coliform pathogens. 'Washing and drying' had a higher probability $(\mathrm{P}<0.001)$ of reducing both the staphylococcal and streptococcal counts on teats compared to 'No preparation', as would be expected. Both 'Chlorhexidine' $(\mathrm{OR}=4.46)$ and 'Wipe' treatments $(\mathrm{OR}=4.46)$ had an increased probability $(P<0.01)$ of reducing the staphylococcal count on teats compared to 'Washing and drying'. Treatments with 'Chlorine' (OR=3.45) and 'Wipes' (3.45) had the highest probability $(\mathrm{P}<0.01)$ of reducing the streptococcal count compared to 'Washing and drying'. Both 'lodine' $(\mathrm{OR}=1.24)$ and 'Chlorhexidine' $(\mathrm{OR}=1.65)$ also tended to have greater probability of reducing streptococcal counts compared to 'Washing and drying'. 'Washing and drying' had a higher probability $(\mathrm{P}<0.05)$ of reducing the coliform count on teats compared to 'No preparation'. Any of the remaining treatments did not enhance reduction in coliform numbers $(\mathrm{P}>0.05)$ compared to 'Washing and drying'.

\section{DISCUSSION}

The microbial count on teats was established before premilking teat preparation was conducted. No differences in the microbial counts were observed on teats, regardless of the post-milking disinfectant products used at the previous milking. Therefore, using different products as a post disinfectant in this study did not influence the outcome of the study. In this study, the use of some disinfectant products for pre-milking teat preparation had beneficial

Table 3: Effect of pre-milking teat preparation treatment in reducing staphylococcal, streptococcal and coliform bacteria counts on teats at two time periods (indoor and outdoor) (\% reduction)

\begin{tabular}{|c|c|c|c|c|c|c|}
\hline \multirow[b]{2}{*}{ Treatment } & \multicolumn{2}{|c|}{ Staphylococcus spp. } & \multicolumn{2}{|c|}{ Streptococcus spp. } & \multicolumn{2}{|c|}{ Coliform } \\
\hline & Indoor & Outdoor & Indoor & Outdoor & Indoor & Outdoor \\
\hline Wash/dry & 50 & 60 & 60 & 45 & 0 & 15 \\
\hline lodine & 65 & 83 & 70 & 44 & 5 & 11 \\
\hline Chlorhexidine & 95 & 75 & 75 & 55 & 5 & 15 \\
\hline Chlorine & 55 & 85 & 65 & 95 & 15 & 15 \\
\hline Wipes & 75 & 95 & 65 & 95 & 0 & 20 \\
\hline No preparation & 0 & 0 & 0 & 0 & 0 & 0 \\
\hline Median & 57 & 78 & 56 & 56 & 4 & 4 \\
\hline
\end{tabular}


Table 4: Estimated odds ratios (OR) and their 95\% confidence intervals (CI) for the effect of pre-milking teat preparation and management period on Staphylococcus spp. (STA), Streptococcus spp. (STR) and coliform (COL) counts

\begin{tabular}{|c|c|c|c|}
\hline Variable & OR & $95 \%$ CI & P-value \\
\hline \multicolumn{4}{|c|}{ Probability of STA } \\
\hline Wash and dry & 1 & & \\
\hline lodine & 2.30 & $0.91-6.09$ & \\
\hline Chlorhexidine & 4.46 & $1.63-13.55$ & 0.01 \\
\hline Chorine & 1.90 & $0.77-4.81$ & \\
\hline Wipes & 4.46 & $1.63-13.55$ & 0.01 \\
\hline No prep & 0.01 & $0.00-0.08$ & 0.001 \\
\hline \multicolumn{4}{|c|}{ Management period } \\
\hline Outdoor & 1 & & \\
\hline Indoor & 0.54 & $0.27-1.02$ & 0.06 \\
\hline \multicolumn{4}{|c|}{ Probability of STR } \\
\hline Wash and dry & 1 & & \\
\hline lodine & 1.24 & $0.51-3.00$ & \\
\hline Chlorhexidine & 1.65 & $0.68-4.05$ & \\
\hline Chorine & 3.45 & $1.34 \cdot 9.47$ & 0.01 \\
\hline Wipes & 3.45 & $1.34-9.4$ & 0.01 \\
\hline No prep & 0.01 & $0.00-0.09$ & 0.001 \\
\hline \multicolumn{4}{|c|}{ Management period } \\
\hline Outdoor & 1 & & \\
\hline Indoor & 0.99 & $0.99-0.54$ & \\
\hline \multicolumn{4}{|c|}{ Probability of COL } \\
\hline Wash and dry & 1 & & \\
\hline lodine & 0.65 & $0.138-2.69$ & \\
\hline Chlorhexidine & 0.79 & $0.19-3.08$ & \\
\hline Chorine & 1.23 & $0.35-4.48$ & \\
\hline Wipes & 0.79 & $0.19-3.08$ & \\
\hline No prep & 0.08 & $0.00-0.73$ & 0.05 \\
\hline \multicolumn{4}{|c|}{ Management period } \\
\hline Outdoor & 1 & & \\
\hline Indoor & 0.28 & $0.09-0.70$ & 0.01 \\
\hline
\end{tabular}

effects on reducing the levels of staphylococcal and streptococcal pathogens on teat skin compared to 'Washing and drying' and 'No preparation'. Where teat preparation is omitted, increased teat colonisation could be expected and this may result in new intramammary infection (Myllys and Rautala 1995). This would concur with the findings of Pankey et al. (1987) who reported that pre-dipping can reduce the rate of intrammamary infection with major mastitis pathogens. Furthermore, Gibson et al. (2008) concluded that most pre-milking teat cleaning treatments reduce the teat total bacterial count, but that cleaning effectiveness was influenced by the type of disinfectant and the application methods. While commercially available disinfectant products may appear to use similar ingredients, the levels and strength of ingredients with additional emollients may influence the success of a product in reducing somatic cell count and improving teat condition over a longer period.

When 'lodine' was used as a pre-milking disinfectant, while it did not significantly reduce bacterial numbers, it was 2.3 times more likely to reduce staphylococcal and 1.24 times more likely to reduce streptococcal counts on teats compared to 'Washing and drying' or no preparation treatments. This result tends to agree with the findings of Ingawa et al. (1992) who demonstrated that iodine reduced the bacterial count on teats compared to washing and drying. The use of a $0.25 \%$ lodine solution pre-milking has also been shown by Oliver et al. (1993) to reduce major pathogen intramammary infections resulting from Streptooccus uberis and dysgalactiae by as much as $49 \%$. However, including 'Iodine' as a pre-milking teat preparation treatment may have implications for milk residues as pre or post dipping with an iodine product can increase iodine levels in milk (Galton et al. 1984). Therefore, correct disinfectant concentration and drying after application with paper towels must be advised to reduce milk residues. 'Chlorhexidine' teat foam which is a new product sold on the Irish market was 4.46 times more likely to reduce the staphylococcal count on teats prior to milking when compared to washing and drying. This is of particular signifance to Irish dairy farmers as Staphylococcus aureus pathogens are to be found in 51\% of Irish bulk milk samples (Kelly et al. 2009). Staphylococcus aureus colonisation on teat ends has been shown to increase the risk of intrammmary infection (Matthews et al. 1992). Therefore, a reduction in staphylococcal numbers on teat ends may reduce the new infection rate on Irish farms. Additionally, it has previously been demonstrated that a disinfectant product containing chlorhexidine, when used as a post disinfectant (Gleeson et al. 2004) and when used as a pre-milking disinfectant over a long time period, reduced the somatic cell count (Wilson et al. 1997). The 'Chlorine' teat foam product used in this study was 3.45 times likely to reduce the streptococcal count on teats prior to milking when compared to the 'Washing and drying' treatment. This is in agreement with Gibson et al. (2008) who showed that a similar chlorine based dip followed by a dry wipe was a most effective treatment for controlling cow mastitis and reducing milk contaminants. The positive effect observed with 'Wipes' in reducing both staphylococcal and streptococcal counts on teats may be due to the physical manipulation of teats combined with the disinfectant. Dry wiping without disinfectant has been shown to reduce the total bacterial count in bulk milk (Murphy et al. 2004). However, the use of dry or wet towels by themselves did not have any significant effect on reducing coliform counts in milk (Galton et al. 1986). In this study, the reduction in the coliform count on teats with any of the teat preparation treatments used was low. This may be influenced by a low initial level of coliform pathogens present on teats prior to treatment. Teat washing combined with drying with individual paper towels reduced staphylococcal, streptococcal and coliform pathogens compared to 'No preparation' and was particularly effective in reducing 
streptococcal counts when used on cows indoors compared to outdoors. This is in agreement with the findings of McKinnon et al. (1990) who concluded that washing and drying teats prior to milking significantly reduced milk bacterial counts during the winter housing period, compared to the pasture summer period. However, the results of this study would indicate that the probability of a reduction in staphylococcal and streptococcal counts could be expected to be greater where a disinfectant is used pre-milking compared to 'Washing and drying' or 'No preparation' treatments. This study shows that the use of some disinfectant products for pre-milking teat preparation can have beneficial effects on reducing the levels of staphylococcal and streptococcal pathogens on teat skin. Therefore, the possibility of bacterial transfer from cow to cow during milking could be expected to be reduced compared to many farm situations where 'No preparation' is normally practiced. The study time period was not sufficient to come to any conclusions on the effect of premilking teat disinfection with regard to teat condition or somatic cell count.

\section{CONCLUSION}

In conclusion, bacterial numbers, specifically staphylococcal and streptococcal numbers on cow teat surfaces, were significantly reduced when disinfection products were applied to teats. The use of wipes was particularly effective due to the physical wiping action in conjunction with the disinfectant application. While the practice of washing and drying did reduce bacterial numbers compared to not cleaning teats at all, it could not be considered to be as effective as cleaning with disinfectant products. Given the level of bacterial numbers on non-prepared teats and the reduction observed with chemical disinfectant, it may be advisable to include this process as part of the milking routine. However, pre-milking teat disinfection must be followed by teat drying using individual paper towels to minimise the possibility of chemical residues in milk.

\section{ACKNOWLEDGEMENTS}

The authors thank Dr. Jim Grant for statistical analysis of the data.

\section{REFERENCE}

Barkema HW, Schukken YH, Lam TJGM et al. (1999) Management practices associated with the incidence rate of clinical mastitis. Journal of Dairy Science 82, 1643-1654.

Berry DP, Amer PR (2006) Proceedings of the Irish Grassland and Annual Production Association, Tullamore, 15-16 March, 32, 80.

Foret CJ, Corbellini C, Young S et al. (2005) Efficacy of two iodine teat dips based on reduction of naturally occurring new intramammary infections. Journal of Dairy Science 88, 426-432.

Galton DM, Adkinson RW, Thomas CV et al. (1982) Effects of pre-milking udder preparation on environmental bacterial contamination of milk. Journal of Dairy
Science 65, 1540-1543.

Galton DM, Petersson LG, Merrill WG et al. (1984) Effects of pre-milking udder preparation on bacterial population, sediment and iodine residues in milk. Journal of Dairy Science 67, 2580-2589.

Galton DM, Petersson LG and Merrill WG (1986) Effects of pre-milking udder preparation practices on bacterial counts in milk and teats. Journal of Dairy Science 69,260-266.

Gibson H, Sinclair LA, Brizuela CM et al. (2008) Effectiveness of selected pre-milking teat-cleaning regimes in reducing teat microbial load on commercial dairy farms. Letters in Applied Microbiology 46, 295300.

Gleeson DE, Meaney WJ and O'Callaghan EJ (2004) Effect of post-milking teat disinfectant on the relationship between teat hyperkeratosis, somatic cell count and the incidence of mastitis. Proceedings of physiological and technical aspects of machine milking, Nitra, Slovak Republic, 26-28 April, 10, 225-227.

Grindal RJ, Bramley AJ (1989) Effect of udder preparation on transmission of Staphylococcus aureus while milking with a multi-valved cluster. Journal of Dairy Research 56, 683-690.

Heinze G, Schemper M. (2002). A solution to the problem of separation in logistic regression. Statistics in Medicine 21, 2409-2419.

Hutchison ML, Thomas DJl, Moore A et al. (2005) An evaluation of raw microorganisms as markers of on-farm hygiene practices related to milking. Journal of Food Protection 68, 764-772.

Ingawa KH, Adkinson RW and Gough RH (1992) Evaluation of a gel teat cleaning and sanitising compound for premilking hygene. Journal of Dairy Science 75, 12241232.

Kagkli DM, Vancanneyt M, Vandamme P et al. (2007) Contamination of milk by enterococci and coliforms from bovine faeces. Journal of Applied Microbiology 103, 1393-1405.

Kelly PJ, O'Sullivan K, Berry DP et al. (2009) Farm management factors associated with bulk tank total bacterial count in Irish dairy herds during 2006/07. Irish Veterinary Journal 62, No 1, 36-42.

Magnusson M, Christiansson A, Svensson B et al. (2006) Effect of different pre-milking manual teat-cleaning methods on bacterial spore milk. Journal of Dairy Science 89, 3866-3875.

Matthews KR, Harmon RJ and Langlois BE (1992) Prevalence of Staphylococcus species during the periparturient period in primiparous and multiparous cows. Journal of Dairy Science 75, 1835-1839

McKinnon CH, Rowlands GJ and Bramley AJ (1990) The effect of udder preparation before milking and contamination from the milking plant on bacterial numbers in bulk milk of eight dairy herds. Journal of Dairy Research 57, 307-318.

Miller RH, Paape MJ, Fulton LA et al. (1993) The relationship of milk somatic cell count to milk yields 
for Holstein heifers after first calving. Journal of Dairy Science 76, 728-733.

Murphy PM, Freyne T, Gleeson D et al. (2004) Impact of pre-milking teat preparation practices on milk quality. Proceedings of Physiological and technical aspects of machine milking, Nitra, Slovak Republic, 26-28 April, ICAR Technical Series 10, 279-280

Myllys V, Rautala H (1995) Characterisation of clinical mastitis in primiparous heifers. Journal of Dairy Science 78, 538-545.

Newbould FHS (1970) Factors contributing to new infections. In: Proceedings Annual Meeting National Mastitis Council. Washington DC. Pp 3.

O'Shea J (1987) Machine milking factors affecting mastitis. IDF Bulletin; 215, 5-32.

Oliver SP, Lewis MJ, Ingle TL et al. (1993) Pre-milking teat disinfection for the prevention of environmental pathogen intramammary infections. Journal of Food Protection, 56, 852-855.

Oliver SP, Gillespie BE, Lewis MJ et al. (2001) Efficacy of a new pre-milking teat disinfectant containing a phenolic combination for the prevention of mastitis. Journal of Dairy Science 84, 1545-1549.

O'Brien B (2008) Practical steps to improve milk quality. Milk Quality Handbook. Teagasc. Pp 104.

Pankey JW, Wildman EE, Drechsler PA et al. (1987) Field trial evaluation of premilking teat disinfection. Journal of Dairy Science 70, 867-872.

Roberson JR, Fox LK, Hancock DD et al. (1994). Ecology of Staphylococcus aureus isolated from various sites on dairy farms. Journal of Dairy Science 77, 3354-3364.

SAS (2004) SAS/STAT ® User's Guide. Cary, NC: SAS Institute Inc.

Vissers MMM, Driehuis F, Te Giffel et al. (2007) Short communication: quantification of the transmission of microorganism to milk via dirt attached to the exterior of the teats. Journal of Dairy Science 90, 3579-3582.

Watts JL, Nickerson SC, Boddie RL et al. (1991) Effects of a $1.94 \%$ sulfonic acid teat dip and $1 \%$ iodophore teat dip on teat canal infections in lactation dairy cows. Journal of Dairy Science 74, 1115-1123.

Wilson DJ, Das HH, Gonzalez RN et al. (1997) Association between management practices, dairy herd characteristics, and somatic cell count of bulk tank milk. Journal of American Veterinary and Medical Association 210, 1499-1502. 